\title{
The Erosion of University Freedom and Autonomy: Nigerian Experience
}

\author{
Mukoro, Akpoyovwaire Samuel \\ Department of Educational Foundation and Administration, \\ College of Education, Warri, Delta State.Nigeria
}

\section{Doi:10.5901/jesr.2013.v3n6p129}

\begin{abstract}
The goals of tertiary education which include the university, are well spelt out in the National Policy on Education. One of the basic characteristic of academic necessity motivating the founding of universities is the need to develop and maintain established academic discipline or areas of knowledge and investigation so as to produce intellectuals, researchers, among others. One way to achieve this was to resist tendencies or development that tends to erode their academic freedom and autonomy. Obviously, universities with predominant academic focus tend to guard their freedom and autonomy very jealously and so remain impervious to new development that tends to erode it. The paper, therefore, examine the concepts of freedom and autonomy. The paper equally examines the indispensability of freedom and autonomy to universities. Also, the paper highlights the issues of erosion of university academic freedom and institutional autonomy in Nigeria. Finally, the paper recommends that government should ensure that universities are managed in line with their statutory laws and acts. In this way each organ of the university such as governing councils, senate, faculties, departments among others will carry out their laid out functions successfully, thus reducing the realities that may have limit university freedom and autonomy.
\end{abstract}

Keywords: Erosion, Institutional, Freedom, Autonomy and University.

\section{Introduction}

The university is the highest citadel of learning for the production of intellectuals, researchers and general workforce for governmental and non-governmental establishments. The federal government of Nigeria in recognition of this emphasized that universities shall be encouraged to disseminate their research result to both government and industries (Federal Republic of Nigeria (FRN), 2004). Collier as cited in Okwor (2001) noted that one of the basic characteristics of academic necessity motivating the founding of universities is the need to develop and maintain established academic disciplines or areas of knowledge and investigation so as to produce intellectuals, researchers, among others. The International Conference convened by the United Nations Educational Scientific and Cultural Organization (UNESCO) in 1950 in Nice, stipulated that universities worldwide should stand on three major principles, which are:

- the right to pursue knowledge for its own sakes and to follow wherever the search for the truth may lead;

- the tolerance of divergent options and freedom from political interference;

- the obligation as social institutions to promote, through teaching and research, the principle of freedom and justice, of human dignity and solidarity, and to lead mutually material and moral aid on an international level.

One way to achieve this was to resist tendencies or a development that tends to erode their academic freedom and autonomy. Obviously, universities with predominant academic focus tend to 
guard their autonomy very jealously and so remain impervious to new development that tends to erode it.

Therefore, it is believed that the ideals of a university are founded on its autonomy and academic freedom to pursue its ultimate functions of training and research. This is perhaps based on the conviction that a university can best serve the needs of the society when it is free to do so according to the dictates of the intellectual enterprise itself. It is therefore the essence of a university to freely pursue knowledge and understanding and to search for the reasons why this happen. This search implies that some of the reasons are known or uncertain and that opinions about them must be questioned (Association of Universities and Colleges of Canada (AUCC) in Arikewuyo \& Ilusanya, 2009). It is an offshoot of its medieval origin. Thus, when the medieval university where founded, individuals were free to pursue secular knowledge of their own choice without being forbidden to do so by the authority of the church (Schofied, 1981). As such, the medieval universities were privileged establishment that enjoy charters which enhanced the safety and freedom of their students and teachers. Nigerian universities like the medieval ones require a large dose of freedom and autonomy. This is because it is the means through which they can carry out their role of teaching and research, as well as, contribute effectively in national growth and development.

However, the issues of university academic freedom and autonomy have continued to generate lots of argument and point of disagreement between successive governments and the Academic Staff Union of Universities (ASUU) in Nigeria. In fact, successive governments have often interfered on university academic freedom and autonomy under the cover of national interest despite the Federal Republic of Nigeria (2004) emphasis that the internal organization and administration of each institution of higher learning shall be its own responsibility. For instance, Olorode (2001:32) stressed that:

.... universities suffered from arbitrary governance ...rather than being a place where justice and truth are to be nurtured, the universities triumphed on mediocrity and untruths. Promotion was earned through sycophancy and the admission procedure became systematically bastardized as wives, children, and the cronies of Vice-Chancellor had their own admission quota without reference to the established procedures. University governance become unpredictable and university finance in shambles.

According to Kerr in Okwor (2001) external authorities are exercising more and more authority over higher education, and institutional independence has been declining. The greatest shift of power in recent years has been taken place not inside the campus but in the transfer of authority from the campus to outside agencies. Giving credence to this, Arikewuyo (2004) reported that forty-nine academic staff of the University of Illorin were dismissed for taking part in a nationwide strike called by ASUU in 2001. This indicated that there is considerable erosion of university academic freedom and autonomy by the Nigeria government.

Against this background, the paper is therefore collapsed into six sections including the brief introduction as one, while section two examine the concepts of freedom and autonomy. In section three the paper examines the indispensability of freedom and autonomy to universities, while section four highlight the various issues of erosion of university academic freedom and institutional autonomy in Nigeria and section five provides a conclusion. The final section concludes the paper with some recommendations.

\section{Definition/Description}

For better understanding we shall define some terms. This in line with the Latinist Maxim thus: initium disputandi est definitio nominis, meaning that for discussion to be intelligible, it should commence with definition of terms. The terms are: 


\subsection{Freedom}

The word "freedom" has a variety of meaning and interpretations. It is a state in which an individual can act without inhibition. Peter as cited in Wokocha (2005) remarked that liberty or freedom suggested that there is lack of impediment or constraint on a person doing what he might want to do. Also, Enemuo (2004) defined freedom to connote immunity from coercion. From these definitions, we can infer that freedom could mean the absence of obstacle or constraints.

Thus, freedom has both the negative and positive notions. A negative notion of freedom views it in terms of absence of inhibition. While the positive notion view it as the ability to choose between alternatives. An example of a positive notion of freedom can be seen in the assertion of Kosemani as cited in Wokocha (2004) that freedom involves and derives from the individual feeling of autonomy. That is the individual capability to decide what he wants himself. In other words, this conception of freedom leads one to master of his destiny. Hence Kalusi (2005) affirmed that freedom implies the capacity to decide what one wants by oneself without interference from any external influence as in say, freedom to marry and form a family, to belong to associations and so on. The positive notion of freedom is in consonance with the existentialists thought that the individual is entirely responsible for his action, freedom or choice. The practicability of the positive notion of freedom is however, only feasible at the realm of freewill. This suggests that man is free, and totally responsible for his action.

However, we are not only interested in the word freedom but the phrase "Academic Freedom". This is to avoid the question "freedom for what?" Now what is academic freedom? Academic freedom in this paper refers to the right scholars have to pursue research, to teach, and to publish without control or restrain from the institutions that employ them (Isichie, 2004). In this regard, Bako (2004) quoted Harvey as saying that academic freedom is the freedom claimed by a college or university professor to write or speak the truth as he sees it without fear of dismissal by his academic supervisor or by authorities outside his college or university. Thus, academic freedom entails granting those who are considered competent in the advancement of knowledge the freedom to pursue whatever line of thought their logic of inquiry demands.

Consequent upon the above, therefore, an academic must be free to voice his opinion no matter how heterodox. By this, it is meant that every member of the academic community will enjoy the right to life, liberty and freedom of thought, conscience, religion, expression, assembly, association and movement. Such right of man as implicated in the concept of academic freedom are as guaranteed by Article 19 of the International Covenant on Civil and Political Rights and Protocol (1966) (Onwuka, 2004 \& Enemuo, 2004).

From the views presented here, we can see that academic freedom suggests the liberty accord the lecturers to pursue research, to teach and investigate, without being debarred by any authority. It gives liberty to academic staff and students to involve in teaching and learning.

\subsection{Autonomy}

Autonomy referred to the right of universities to govern themselves without outsides control. It therefore denote self-governance or independence and academic freedom of universities to pursue their work within the limit of the law establishing them. Specifically, the United Nation Educational, Scientific and Cultural Organization (UNESCO) general conference has proclaimed autonomy as the institutional form of academic freedom and necessary precondition to guarantee the proper fulfillment of the function entrusted to higher-education teaching personnel and institutions. Bukar (2004) opined that autonomy of university is a frame work of self-governance in which the universities is at liberty:

1. To design its own curricular and determine priorities in regard to teaching and research;

2. To set its own standards and determine its own procedures for examination;

3. To decide the criteria for admission of students; 
4. To select and appoint its teaching staff and administrators and to determine their condition of service; and

5. To determine and decide the allocation of available financial resources among competing demands.

Earlier, the World University Services in Babarinde (2004) possibly drawing from similar analysis affirms through the Lima Declaration on academic freedom and autonomy of institutions of higher education that autonomy means independence of institutions of higher education from the state and all other forces of society to take the decisions regarding its internal government-finance, administration, and to establish its policies of education, research, extension work and other related activities.

In a rather concise manner, Adegbite as cited in Fabunmi, (2005) identified three measures of autonomy:

1. Administration autonomy, that is, the freedom to manage its internal affairs and select its chief executives;

2. Academic freedom, that is, the freedom to decide whom to teach or admit, what to teach or research into and how to examine; and

3. Financial autonomy, that is, the freedom to generate and disburse funds.

In short, university autonomy to Wokocha (2004) entails the right of the institution to govern itself insulated from the day-to-day interference of the state and the interplay of both civilian and politician. From our definitions so far, we can observe that institutional autonomy is the right academic institutions have to self-governance and to control all the sphere of their internal arrangements or activities. We can also conclude that autonomy means the degree to which a university enjoys freedom to administer its day-to-day affairs without external interference. In effect any erosion of such ideas by extraneous forces might to prelude to lowering of standards. These features of autonomy do not however abrogate the responsibility to account for the public funds invested in the management of the university. They do not also portend that government should shirk her responsibility of effective funding of the institutions she establish for the education of the citizenry (Wokocha, 2004).

\section{Indispensability of Freedom and Autonomy to Universities}

Freedom and autonomy are indispensable to universities in many ways. They form the basis of the enabling environment for the appropriate discharge of the responsibilities of academic and the academic institutions (Babaride, 2004). The National Policy on Education (FRN, 2004) stipulated the essentials of academic freedom to include freedom to select their students, appoint staff, teach, select area of research and determine the content of courses. It equally covers the internal organizations and administrations of each institution. Thus, freedom is essential to universities, hence, crisis in university system in Nigeria is usually triggered off by what such as inadequate financial support from the government and undue interference in the internal administration of the universities occasioned by the establishment circular from the Federal Ministry of Education on the National Universities Commission (NUC). It is clear that there are contradiction in what the National Policy on Education provides as academic freedom for the universities and what is operational. What is operational is clearly centralized interference and control from the government through its agencies, masquerading as champions and defenders of academic freedom for universities (Bako, 2004).

Also, autonomy is very essential to universities in Nigeria. Harman as cited in Okwor (2001), listed some of the reason as first autonomy, for most universities, is a traditional right, which has worked well over the year, the responsibilities of creating new knowledge through scholarship and research, transmitting and preserving culture developing the capacity in students for critical and independent judgment; and cultivating aesthetic sensitivities are carried out best in environments free from direct external control and domination. The complexity of academic works requires a far 
measure of independence. Autonomy provides for both staff and students checks and balances in a democratic society.

Consequently, it can be argued that autonomy is essential to Nigerian universities to reduce interference by external agents or politicians into the university affairs. It is in this regards that Academic Staff Union of Universities (1981) listed the dangers imminent in absence of autonomy to include: universities inabilities to pursue their sacred functions: scholars being force to owe loyalty to the party in power, with the consequence of political consideration rather than concern for truth being the decisive factor in determining intellectual issues, loss of job security; university councils becoming rubber stamps for government decisions and inevitable fall of standards.

Universities in Nigeria are established for definite purpose. The goals of tertiary education which include the university, are well spelt out in the National Policy on Education (FRN, 2004) Section (8) (59) of the policy document. In this regard Enemuo (2004) remarked that mindful of the enormity of such a tall order and cognizant of their attribute as the font and store-house of knowledge, it can never be over-emphasized that tertiary institution in Nigeria rightly deserves academic freedom and institutional autonomy. Hence UNESCO charge member states with an obligation to protect higher educational institutions from threats to their autonomy. In short both Happouf and Ward as cited in Okwor (2001) believed that the state has something to gain from autonomy for university. They emphasized that the state should remained convinced that universities will achieve the state's purpose and that universities should be free to play an active role in society as it custodian of knowledge and free inquiry, as teachers and researchers, as defenders of higher intellectual standards. To this end, Montford quoted in Wokocha (2004) stated with university autonomy as it is formulation, the principle of academic freedom ensures the right of the institution itself and each member of its academy staff to teach, research and make public the results of scholars work in the interest of truth and advancement of learning alone, uninhibited and unfettered by any extraneous consideration whatsoever. This suggests that academic freedom is not apart from institutional autonomy. Therefore, freedom and autonomy are defensible. For instance, the academic freedom doctrine, apart from being an essential ingredient in a bourgeoning democratic society like Nigeria, is also a critical factor to reckon with as a catalyst for actualizing educational aims (Enemuo, 2004). While autonomy facilitate the university's educational research and social responsibilities, external control would be destructive of its functions.

In a nutshell, freedom and autonomy are essential for universities in Nigeria if they are to guarantee that teachers and students will be able to carry on the function of learning, research and teaching with a minimum of restriction and to guarantee the independence of institution of higher education from the state and all other forces of society to take decision regarding its internal government-finance, administration and to establish its policies of education, research, extension works and other related activities (Enemuo, 2004, Babarinde, 2004).

\section{Erosion of University Academic Freedom and Autonomy in Nigeria}

Evidences abound where government has eroded university freedom and autonomy in Nigeria. They include:

1. In 1972, General Gowon appointed Vice Chancellor for the University of Lagos without reference to governing council of the university. This type of appointment also happened under the leadership of General Murtala Muhammed in 1975.

2. In 1987, Babangida's regime removed ASUU from membership of the Nigeria Labour Congress, proscribed ASUU in 1988 and 1992 for embarking on strikes over the poor state of the universities and demoralizing conditions of service. Babangida's regime sack academics who defended political views that where radically different from governments. This regime used Decree 17 of 1984 to dismiss two Obafemi Awolowo University (O.A.U.) and one University of Ibadan (U.I.) Academics in the public interest.

3. The regime of General Abacha almost completed the destruction of university autonomy. 
It recruited many Vice Chancellors who had no regard for university statute (Onwuka, 2004:57 - 58).

In addition, Arikewuyo (2004: 128) recounted how various governments have encroached on university autonomy in Nigeria as follows:

...staff and students union were banned and unbanned at various times. The ASUU and NANS were the worst affected. Many vice chancellors have been removed for not complying with directives from the government. A Major General was even appointed as a sole administrator in a first generation university. Many academics have been dismissed, retired and unjustly jailed for teaching what they were not employed to teach.

According to Arikewuyo and Ilusanya (2009) between 1992 and 1998, for instance, sole administrators were appointed for the following Nigerian universities: Ahmadu Bello University (ABU) Zaria (Retired General), University of Nigeria, Nsukka (UNN), Federal University of Technology (FUT) Minna, University of Maiduguri, Ladoke Akintola University (LAUTECH) Ogbomoso, and Edo State University, Ekpoma. As a matter of fact, Babarinde (2004:26) captured the picture of Nigerian universities in this way:

...the recent attack on the Nigerian intellectual community by the Federal Government of Nigeria through refusal to honour agreement with the Academic Staff Union of Universities (ASUU), support to the arbitrary sacking of lecturers at the University of Illorin, attempt to force arbitrary rule on universities through the Federal Government sponsored Autonomy Bill and when that failed, another attempt to jettison already passed and assented Bill which did not contain government positions. The attitude of president Obasanjo's administration towards the Academic Staff Union of Universities in particular and all trade unions in general are evidences of lack of academic freedom and institutional autonomy.

The then President of the Federal Republic of Nigeria, Chief Olusegun Obasanjo affirmed at various convocations fora before he left office that there would be no reprieve for the sacked lecturers at the University of Illorin (Arikewuyo, 2004). This suggests that there are realities that exert considerable erosive influences on academic freedom and institutional autonomy in Nigeria universities. Table 1 below showed some areas of government interference on university governance in Nigeria.

Table 1: Areas of government interference on university governance

\begin{tabular}{|c|l|}
\hline $\boldsymbol{S} / \boldsymbol{N}$ & $\begin{array}{c}\text { Governance, Staff, Administration and Finance, } \\
\text { Academic Standard and Students }\end{array}$ \\
\hline 1. & Membership of the governing councils \\
\hline 2. & Control of governing councils \\
\hline 3. & Appointment of vice-chancellor \\
\hline 4. & Dismissal of vice-chancellor and principal officers \\
\hline 5. & Pay and conditions of service \\
\hline 6. & Number of students \\
\hline 7. & Closure or amalgamation of courses \\
\hline 8. & Length of courses \\
\hline 9. & Duration of the academic years \\
\hline 10. & Financial audit \\
\hline 11. & University budget \\
\hline 12. & Approval of major capital expenditure \\
\hline 13. & Level of tuition fees \\
\hline 14. & Financial aid to students \\
\hline
\end{tabular}




\begin{tabular}{|l|l|}
\hline 15. & Quality control \\
\hline 16. & Accreditation of courses \\
\hline 17. & Quota for minority groups \\
\hline 18. & Introduction to new teaching fields \\
\hline
\end{tabular}

Source: Adopted from Arikewuyo, M.O. \& Ilusanya, G. (2009). University Autonomy in a Third Generation University in Nigeria

Also, undue interference in university governance and under-funding have limit and erode academic freedom and institutional autonomy, which have adverse effect on the capacity of universities and academic to carry out their statutory functions of teaching and research (Bako, 2004). Bukar (2004) noted that the block grants promised to the universities have been inadequate and irregular. The quarterly grant given to the universities hardly pay staff salary, hence, Vicechancellors, had to source for the shortfall before salaries are paid every month. To this end, Enemuo (2004) reported that since 1999, allocation to this sector of the economy has shamelessly move from $8.36 \%$ (in 2000) to 7\% (in 2001), 5.9\% (in 2002) and 1.83\% (in 2003). The Central Bank of Nigeria Annual Report 2003 - 2007 in Nwadiani (2012) show that the average capital and recurrent expenditure of all governments on education between years 2003 - 2007 was put at N270.184 billion. Even more specifically, the nation budgeted N249.08 billion to education out of its N4.07 trillion budget in 2010 which was a paltry 6.1\%. Furthermore, table 2 presents the Federal Government disbursement allocation to education sector from 2000 - 2010.

Table 2: Budgetary allocation to education 2000 - 2010

\begin{tabular}{|c|c|}
\hline Year & Percentage \% \\
\hline 2000 & $11.2 \%$ or $N 23.047 \mathrm{bn}$ \\
\hline 2001 & $8.3 \%$ or $\mathrm{N} 44.225 \mathrm{bn}$ \\
\hline 2002 & $7.0 \%$ or $\mathrm{N} 39.885 \mathrm{bn}$ \\
\hline 2003 & $5.09 \%$ or $\mathrm{N} 100.2 \mathrm{bn}$ \\
\hline 2004 & $11.83 \%$ or $\mathrm{N} 64.76 \mathrm{bn}$ \\
\hline 2005 & $7.81 \%$ or $N 72.22$ bn \\
\hline 2006 & $8.3 \%$ or $\mathrm{N} 92.59 \mathrm{bn}$ \\
\hline 2007 & $8.7 \%$ or N166.6 bn \\
\hline 2008 & $6.07 \%$ or N137.48 bn \\
\hline 2009 & $13 \%$ or $N 137.48$ bn \\
\hline 2010 & $\begin{array}{l}\text { N249 bn (this is less than } 10 \% \text { ). Later reviewed } \\
\text { upward to } 495.3 \text { bn or } 6.4 \%\end{array}$ \\
\hline
\end{tabular}

Source: Deji-Folutile, O. The Punch Friday, April 30, 2010, p. 40

Obviously, the erosion of universities academic freedom and abuse of institution autonomy by these realties have resulted in various conflicts and strike action in Nigeria. For example, in August 1999, ASUU called out its members on a strike following the refusal of the government of Chief Olusegun Obasanjo to recognize an agreement between ASUU and the previous regime on May 25, 1999. Also, on April 2, 2001, ASUU yet again declared a strike after failing to get government to sign an agreement negotiated with it and concluded December 18, 2000. Several attempts were made to avert the crisis by ASUU. Following the failure to get a hearing from government, ASUU declared a trade dispute with government and proceeded on a strike about four weeks later. Another strike was declared in December 2002 and lasted till June, 2003. ASUU has endured these great pains to itself and its members for one thing and one thing alone, the restoration of the academic freedom of Nigerian universities to enable them to compete favourably in the 
international market of knowledge. (Bako, 2004).

\section{Conclusion}

An attempt has been made in this paper to highlight the essential of freedom and autonomy to universities in Nigeria. It equally analyzed the realities that limit or erode universities academic freedom and institutional autonomy. The essence of freedom and autonomy is that it is crucial to the facilitation of research and social responsibilities, as well as, the growth of knowledge, intellectual standard and imparting of knowledge. In this regard, the society must not erode the academic freedom and autonomy enjoy by the universities. Unfortunately, it is very glaring that Nigeria has not done well when it comes to the guarantee of academic freedom and institutional autonomy of universities. Hence the frequent strike action, inadequate funding, lack of facilities and, ultimately, drop in quality in Nigeria universities.

\section{Recommendations}

- In view of the situation analysis so far the freedom and autonomy of universities should be strongly protected so as to avoid influence on their founding objectives. This will lead to the preservation of the university status quo and will, ultimately reduce dispute, strike action and eventual disruption of academic programmes in the universities.

- Government should ensure that universities are managed in line with their statutory laws and acts. In this way each organ of the university such as governing councils, senate, faculties, departments among others will carry out their laid out functions successfully, thus reducing the realities that may have limit university freedom and autonomy.

- Universities should be given the required funding for their rolling plans to enable them run their affairs unhibited by the government. This means that government after provision of the required funds should hands-off the affairs of the universities to the Governing Councils, Vice-Chancellors, Senate, Faculties, Departments etc. to determine policy directions concerning prudent utilization of funds, materials and human resource. This is because the universities have the right to run their affairs in accordance with the law and statutes setting them up. In fact, statutes of university allow internal democratic governance through the committee system. In this way, what the universities management need to do is to account for fund disbursed to them by the government.

- Government should desist from interfering in the affairs of universities on minor administrative matters. Universities should be given the chance to explore their established internal statutory mechanisms in resolving administrative and provocative issues.

\section{References}

Academic Staff Union of Universities (1981). Memorandum presented at the Presidential Commission on the state of Nigeria universities and the conditions of services of university staff. Ibadan: National Secretariat.

Arikewuyo, M.O. \& Ilusanya, G. (2009). University autonomy in a Third-Generation University in Nigeria. Benin Journal of Educational Studies, 19 (1\& 2); 164 - 182.

Arikewuyo, M.O. (2004). Democracy and university education in Nigeria: Some constitutional considerations. Higher Education Policy and Management, J ournal of the Organization of Economic Co-operation and Development (OECD), 16 (3); 121 - 134.

Babarinde, K. (2004). Is there a local relationship between autonomy and quality in higher education? Nigerian Journal of Educational Philosophy, 11 (1); 20 - 21.

Bako, R.B. (2004). Academic freedom or academic anarchy; What exactly do Nigeria academic want? Nigerian Journal of Educational Philosophy, 11 (1); 43 - 51. 
Bukar, K. (2004). Institutional autonomy and academic freedom in Nigeria: A university perspective. Nigerian Journal of Educational Philosophy, 11 (1); 61 - 70.

Deji-Folutile, O. (2010). Private universities to the rescue. The Punch, April 30, p. 40.

Enemuo, P.C. (2004). Academic freedom and autonomy: A condition precedent for educational accountability. A paper presented at the National Conference of the Philosophy of Education Association of Nigeria (PEAN) held at the University of Maiduguri, Borno State, Nigeria, $11^{\text {th }}-14^{\text {th }}$ October.

Fabunmi, M. (2005). Trade off issue among access, equity, autonomy, quality and sustainability in a deregulated Nigeria university education. In Akpa, G.O., Udoh, S.U. \& Fagbamiye, E.O. (eds) Deregulating the Provisions and Management of Education in Nigeria. Jos: The Nigeria Association for Educational Administration and Planning (NAEAP).

Federal Republic of Nigeria (2004). National Policy on Education. Lagos: NERDC.

Isichie, F.M. (2004). Freedom and professional responsibility in the educational process. Nigerian Journal of Educational Philosophy, 11 (1); 89 - 95.

Kalusi, J.I. (2005). An Introduction to Philosophy of Education. Warri: COEWA Publishers.

Nwadiani, M. (2012). Financing education in Nigeria: Options, challenges and implications for national development. In R.O. Olubor, S.O. Okotete \& F. Adeyanju (eds) Resources Management in Education and National Development. Benin-City: Institute of Education, University of Benin, BeninCity.

Okwor, R.E. (2001). Constraints to university autonomy: The Nigeria perspective. In Akubue, A.U. \& Enyi, D. (eds) Crises and Challenges in Higher Education in Developing Countries: A Book of Reading. Ibadan: Wisdom Publishers.

Olorode, L. (2001). Democratic imperatives and higher education in Nigeria: The quest for social justice. Proceedings of the $12^{\text {th }}$ General Assembly of the Social Science Academy of Nigeria; $29-36$.

Onwuka, C.J.A. (2004). Nigeria's educational autonomy: A philosophical appraisal. Nigerian Journal of Educational Philosophy, 11 (1); 52 - 60.

Schofied, H. (1981). The Philosophy of Education: An Introduction. London: George Allen and Unwin Publishers Ltd.

Wokocha, A. (2004). Educational autonomy and freedom within the law. A presidential address at the National Conference of the Philosophy of Education Association of Nigeria (PEAN) held at the University of Maiduguri, Borno State, Nigeria, $11^{\text {th }}-14^{\text {th }}$ October. 
